\title{
Apoptosis and antimigration induction in human skin cancer cells by rhodomyrtone
}

\author{
MALATEE TAYEH ${ }^{1}$, SIRINUN NILWARANGKOON ${ }^{1}$, CHANTRA TANUNYUTTHAWONGSE $^{1}$, \\ WILAWAN MAHABUSARAKUM ${ }^{2}$ and RAMIDA WATANAPOKASIN ${ }^{1}$
}

\author{
${ }^{1}$ Department of Biochemistry, Faculty of Medicine, Srinakharinwirot University, Bangkok 10110; ${ }^{2}$ Department of Chemistry, \\ Faculty of Science, Prince of Songkla University, Hat Yai, Songkhla 90110, Thailand
}

Received January 8, 2017; Accepted March 9, 2018

DOI: $10.3892 /$ etm.2018.6044

\begin{abstract}
Rhodomyrtone is a bioactive compound extracted from Rhodomyrtus tomentosa leaves. It has been used as a traditional herb medicine for many years. Rhodomyrtone exhibits antibacterial activity, anti-inflammatory and antioxidant activities. However, the anticancer activity of rhodomyrtone has not been previously reported. The present study investigated the anticancer effect of rhomyrtone on human epidermoid carcinoma A431 cells. The cytotoxic and antiproliferative effects of rhodomyrtone on A431 cells were investigated by an MTT assay. Cell morphological alterations and apoptotic cells were observed with Hoechst 33342 staining following rhodomyrtone treatment. Flow cytometry and western blotting were performed to detect cell cycle and apoptosis induction. The results demonstrated that rhodomyrtone inhibited proliferation of A431 cells in a dose-dependent manner with $\mathrm{IC}_{50}$ value of $8.04 \pm 0.11 \mu \mathrm{g} / \mathrm{ml}$. The results also indicated that rhodomyrtone increased chromatin condensation, nuclear fragmentation and apoptotic bodies in treated A431 cells in a time-dependent manner. Apoptosis was also induced through the activation of caspase-7 and poly (ADP-Ribose) polymerase cleavage. Flow cytometry analysis revealed that rhodomyrtone induced cell cycle arrest at the G1 phase. Notably, the non-toxic concentration of rhodomyrtone markedly inhibited A431 cell migration in a dose- and time-dependent manner. These finding suggested that rhodomyrtone may be used as an anticancer agent for human skin cancer.
\end{abstract}

\section{Introduction}

Rhodomyrtus tomentosa (Aiton) Hassk., a traditional herb medicine belongs to the family Myrtaceae. It is native to Southeast

Correspondence to: Professor Ramida Watanapokasin, Department of Biochemistry, Faculty of Medicine, Srinakharinwirot University, 23 Sukhumvit, Bangkok 10110, Thailand

E-mail: ramidawa@yahoo.com; ramidaw@g.swu.ac.th

Key words: rhodomyrtone, cell cycle arrest, cell migration, apoptosis, human epidermoid carcinonoma
Asia and a troublesome invader of native plant communities in Florida. It is used for treatment of diarrhea (1), gastrointestinal (2), urinary tract infections (3), anti-inflammation (4) and as an antiseptic wash for wounds (5). In addition, it is used to formulate skin whitening, anti-aging and skin beautifying agent (6). Rhodomyrtone (Fig. 1), a pure compound in acylphloroglucinol class isolated from Rhodomyrtus tomentosa leaves. Previous studies have shown that rhodomyrtone displays antibacterial activity against a wide range of gram-positive bacteria such as Bacillus subtilis, Enterococcus faecalis, Staphylococcus aureus, Staphylococcus epidermidis, Streptococcus spp., and methicillin-resistant Staphylococcus aureus (MRSA) (7-10). Moreover, some reports indicated that rhodomyrtone stimulated pro- and anti-inflammatory cytokine responses (11) and reduced hyperproliferation and abnormal differentiation of $\mathrm{HaCaT}$ cells (12). However, the anticancer activity of rhodomyrtone on cancer cells has not been reported.

Skin cancer is the most common type of cancer in the world, especially in white-skinned individuals. The increasing incidence rate has been shown worldwide. There are two main types of skin cancer: Melanoma or malignant melanoma (MM) and non-melanoma skin cancer (NMSC), including the basal cell carcinomas (BCCs) and squamous cell carcinomas (SCCs) $(13,14)$. SCC is the second most common skin cancer, accounting for about $20 \%$ of NMSC cases. It is more common in older people. The major cause of developing SCC is exposure to UV radiation, which causes cellular damage $(15,16)$. Current treatments of SCCs consist of surgery, photodynamic therapy, radiation therapy, chemotherapy or combination therapy, but these treatments are however unsatisfactory. Thus, it is necessary to search for a new effective therapeutic agent to inhibit SCCs.

In this study, we first investigated the effect of rhomyrtone on cell proliferation and migration of A431 cells. It was demonstrated that rhodomyrtone effectively inhibited growth and migration associated with G1 arrest and apoptosis induction in human epidermoid carcinoma A431 cells.

\section{Materials and methods}

Reagents and chemicals. Rhodomyrtone was dissolved in dimethylsulfoxide (DMSO). MTT (3-4,5-dimethyl-2,5diphenyl tetrazolium bromide), DMSO and trypan blue were 
purchased from Sigma-Aldrich (St. Louis, MO, USA). Guava Cell Cycle ${ }^{\circledR}$ reagent was purchased from Merck Millipore (Darmstadt, Germany) and Hoechst 33342 dye was purchased from Invitrogen; Thermo Fisher Scientific, Inc. (Waltham, MA, USA). Rabbit monoclonal antibodies against caspase-7, cleave-PARP, anti-mouse immunoglobulin $\mathrm{G}$ and anti-rabbit immunoglobulin $\mathrm{wG}$ horseradish peroxidase-conjugated secondary antibodies were obtained from Cell Signaling Technology, Inc. (Danvers, MA, USA), and mouse monoclonal antibody against $\beta$-actin was obtained from Merck Millipore.

Cell culture. The human epidermoid carcinoma cells (A431) was obtained from American Type Culture Collection (Manassas, VA, USA). A431 cells were maintained as a monolayer in Dulbecco's modified Eagle's medium (DMEM; Gibco; Thermo Fisher Scientific, Inc.) containing $10 \%$ fetal bovine serum, $100 \mathrm{U} / \mathrm{ml}$ penicillin $\mathrm{G}$ and $100 \mu \mathrm{g} / \mathrm{ml}$ streptomycin (GE Healthcare Life Sciences, Chalfont, UK) and $3.7 \mathrm{~g} / 1$ sodium bicarbonate into $75 \mathrm{~cm}^{2}$ cell culture flasks and grown under a $95 \%$ humidity, $5 \% \mathrm{CO}_{2}$ atmosphere at $37^{\circ} \mathrm{C}$.

Cell viability assay. The effect of rhodomyrtone on cell viability of A431 cells was determined by using MTT (3-(4,5-dimethylthiazol-2-yl)-2,5-diphenyl-2H-tetrazolium bromide) assay. Cells were seeded in 96-well plates at density of $7.0 \times 10^{3}$ cells/well and incubated overnight. Then, the cells were treated with various concentrations $(0-100 \mu \mathrm{g} / \mathrm{ml})$ of rhodomyrtone for $24 \mathrm{~h}$. After treatment, $0.5 \mathrm{mg} / \mathrm{ml}$ MTT solution was added to each well and the plates were further incubated for $2 \mathrm{~h}$ at $37^{\circ} \mathrm{C}$. The supernatant was removed and $200 \mu \mathrm{l}$ DMSO was added to each well to solubilize water insoluble purple formazan crystals. The absorbance was measured using an Epoch ${ }^{\mathrm{TM}}$ Microplate spectrophotometer at $570 \mathrm{~nm}$ and the percentage of cell survival (\%) was calculated relative to the control. The half maximal inhibitory concentration $\left(\mathrm{IC}_{50}\right)$ value was calculated using the software GraphPad Prism 3.03 (GraphPad Software, Inc., San Diego, CA, USA). Cell viability assay was performed with three independent experiments.

Wound healing assay. The effect of rhodomyrtone on cell motility was determined by wound healing scratch assay (17). A431 cells were seeded in 6-well plate and allowed to grow until $90 \%$ confluence. After that the monolayers were scratched with a micropipette tip, the cellular debris was removed by washing with PBS and treated with non-toxic concentrations $(0,0.5,1.5 \mu \mathrm{g} / \mathrm{ml})$ of rhodomyrtone for 12 and $24 \mathrm{~h}$. The wound area was photographed with an inverted microscope (Olympus, Tokyo, Japan) and measured by using Image $\mathbf{J}$ software.

Apoptotic cells staining with Hoechst 33342 dye. A431 cells were seeded in a 6 -well plate at $3 \times 10^{5}$ cells/well and treated with $15 \mu \mathrm{g} / \mathrm{ml}$ rhodomyrtone for $0,3,6,9$ and $12 \mathrm{~h}$. The cells were then stained with Hoechst 33342 for 15 min. The apoptotic cells were observed using a fluorescence microscope IX73 model (Olympus) with an ultraviolet filter.

Cell cycle analysis. A431 cells were seeded in a 6-well plate at density $3 \times 10^{5}$ cells/well and then treated with $15 \mu \mathrm{g} / \mathrm{ml}$ rhodomyrtone for $0,3,6,9$ and $12 \mathrm{~h}$ at $37^{\circ} \mathrm{C}$. After treatment, whole cells were collected and stained with Guava Cell

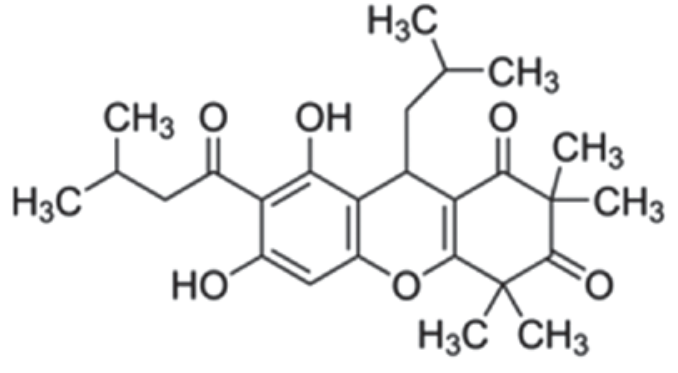

Figure 1. Chemical structure of rhodomyrtone.

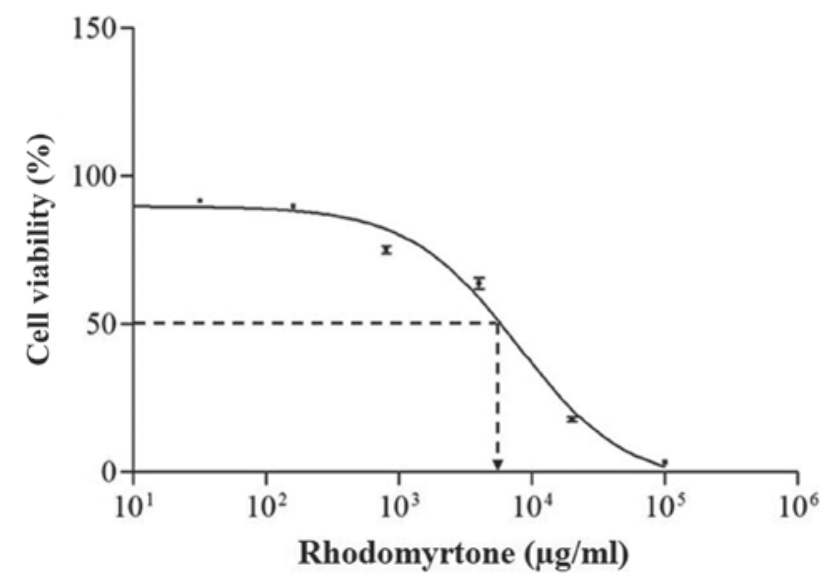

Figure 2. Effect of rhodomyrtone on A431 cell proliferation. The effect of rhodomyrtone on A431 cell proliferation was determined by MTT assay. Cells were treated with various concentrations of rhodomyrtone $(0-100 \mu \mathrm{g} / \mathrm{ml})$ for $24 \mathrm{~h}$. The $\mathrm{IC}_{50}$ was $8.04 \pm 0.11 \mu \mathrm{g} / \mathrm{ml}$.

Cycle ${ }^{\circledR}$ reagent (Merck Millipore). The stained cells were then sorted and analyzed for DNA content by a Guava easyCyte $^{\mathrm{TM}}$ flow cytometer and GuavaSoft ${ }^{\mathrm{TM}}$ software (Merck Millipore).

Western blot analysis. A431 cells were seeded in a 6-well plate at density $3 \times 10^{5}$ cells/well and then treated with $15 \mu \mathrm{g} / \mathrm{ml}$ rhodomyrtone for $0,3,6$ and $9 \mathrm{~h}$ at $37^{\circ} \mathrm{C}$. After treatment, total protein was extracted with RIPA lysis buffer $(50 \mathrm{mM}$ Tris- $\mathrm{HCl}$, $\mathrm{pH} 7.4,1 \% \mathrm{NP}-40,0.5 \% \mathrm{C}_{24} \mathrm{H}_{39} \mathrm{NaO}_{4}, 0.1 \%$ SDS, 150 western blotting was performed. Then, the membranes were blocked with 5\% skimmed-milk in TBS-Tween buffer for $1 \mathrm{~h}$ at room temperature, and incubated with monoclonal antibody against cleave-PARP, caspase-7 and $\beta$-actin overnight at $4^{\circ} \mathrm{C}$. After incubation with anti-mouse immunoglobulin $\mathrm{G}$ or anti-rabbit immunoglobulin $\mathrm{G}$ horseradish peroxidase-conjugated secondary antibodies, visualization of proteins was developed by using Immobilon ${ }^{\mathrm{TM}}$ Western chemiluminescent HRP substrate (Merck Millipore) and Chemiluminescent Imaging system (GeneGnome gel documentation; Synoptics, Ltd., Cambridge, UK).

Statistical analysis. Data are expressed as mean \pm SD of three independent experiments. Statistical analysis was determined by using student's t-test or one-way analysis of variant (ANOVA). Differences were considered statistically significant at $\mathrm{P}<0.05$. All statistical analyses were performed using SPSS 17.0 software (SPSS, Inc., Chicago, IL, USA). 
$\mathbf{A}$
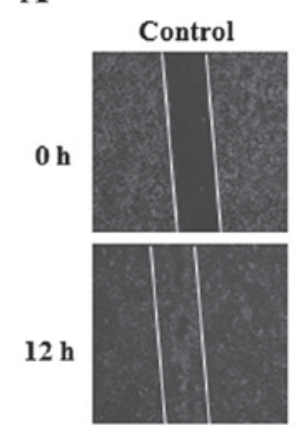

$24 \mathrm{~h}$

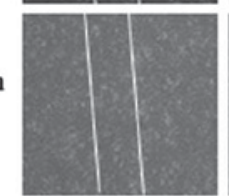

Rhodomyrtone $(\mu \mathrm{g} / \mathrm{ml})$
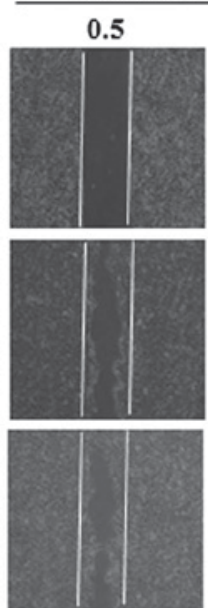
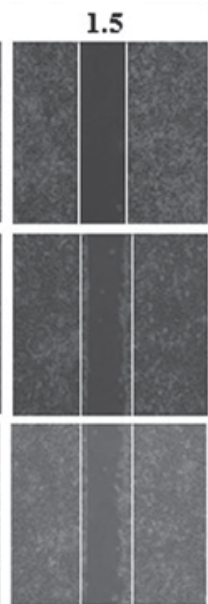

B

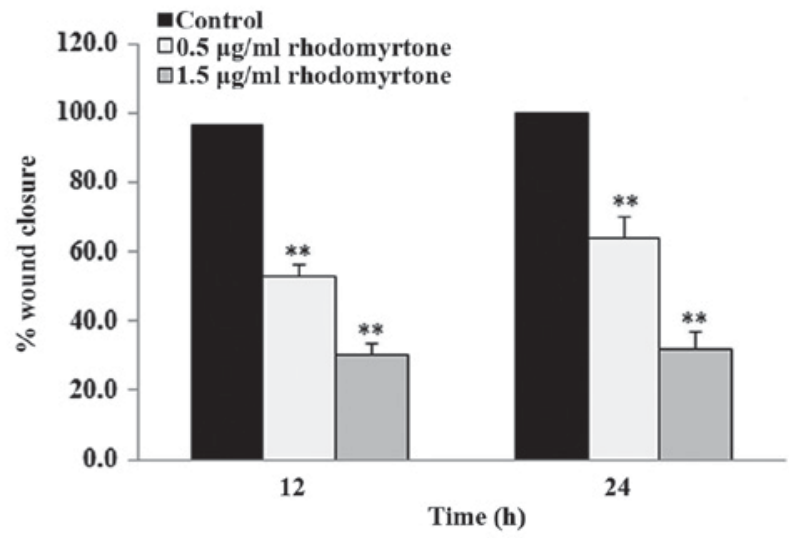

Figure 3. Effect of rhodomyrtone on A431 cell migration. Cell monolayers were scratched by a sterile micropipette tip and the cells were treated with the non-toxic concentrations $(0.5$ and $1.5 \mu \mathrm{g} / \mathrm{ml})$ of rhodomyrtone for 12 and $24 \mathrm{~h}$ (A) A431 cells migrated to the wound area were photographed (magnification, $\mathrm{x} 10$ ). The wound closure of A431 cells (B) were analyzed in four fields in each treatment, and data was calculated from three independent experiments. Data are presented as means $\pm \mathrm{SD}(\mathrm{n}=3) .{ }^{* *} \mathrm{P}<0.01$ compared with the untreated control.
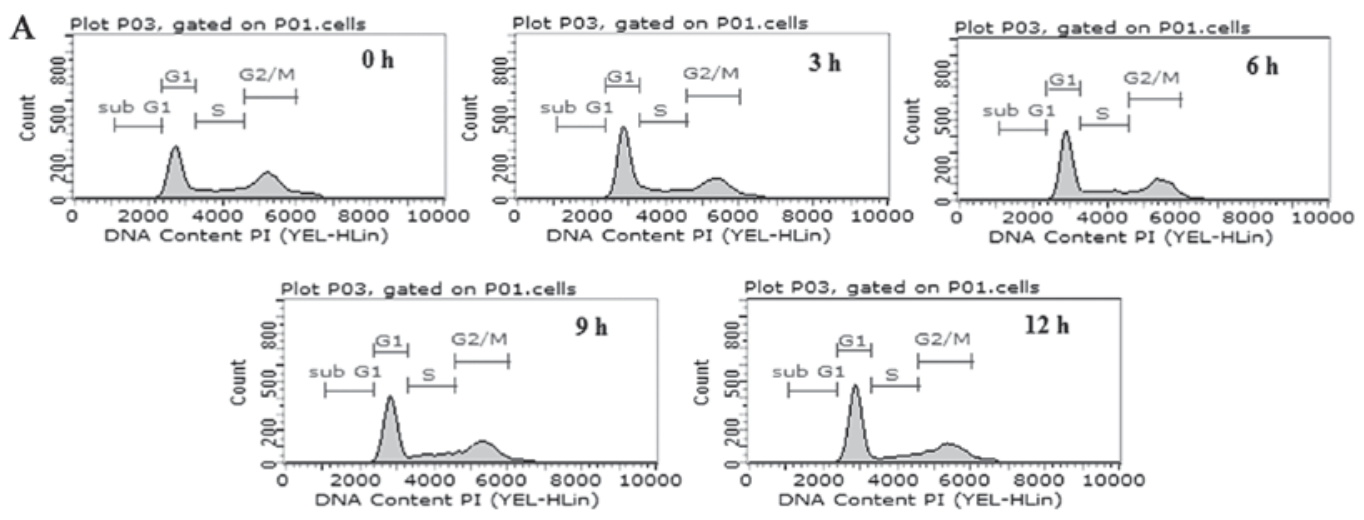

B

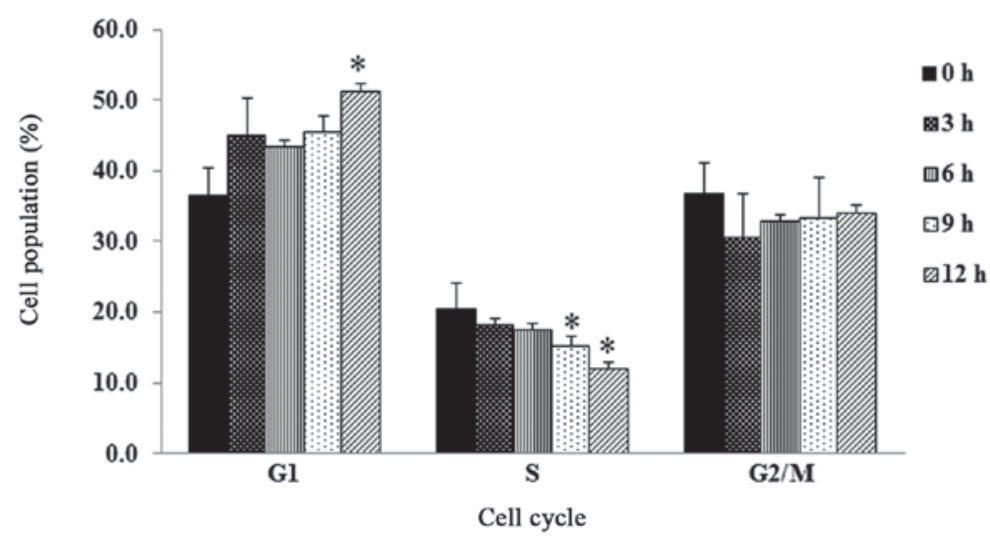

Figure 4. Effects of rhodomyrtone on cell cycle in A431 cells. (A) Cells were treated with $15 \mu \mathrm{g} / \mathrm{ml}$ of rhodomyrtone for 0,3,6,9,12 h. Cell cycle was detected by flow cytometer, G1, S, G2/M indicates the cell cycle phase. (B) The percentage of cells in the G1 phase was increased with concomitantly decreased S phase cells. Data are presented as mean $\pm \mathrm{SD}(\mathrm{n}=3) .{ }^{*} \mathrm{P}<0.05$ compared with the control.

\section{Results}

Rhodomyrtone inhibited cell proliferation of A431 cells. A431 cells were treated with various concentrations of rhodomyrtone $(0-100 \mu \mathrm{g} / \mathrm{ml})$ for $24 \mathrm{~h}$ and cell proliferation was analyzed by MTT assay. The result showed that rhodomyrtone inhibited cell proliferation in a dose-dependent manner as shown in Fig. 2. At high concentrations, rhodomyrtone significantly inhibited A431 cell proliferation while at the concentration lower than $3 \mu \mathrm{g} / \mathrm{ml}$ did not. The $\mathrm{IC}_{50}$ of rhodomyrtone on A431 cells was $8.04 \pm 0.11 \mu \mathrm{g} / \mathrm{ml}$. This result indicated that rhodomyrtone inhibited cell proliferation of A431 cells, thus $15 \mu \mathrm{g} / \mathrm{ml}$ rhodomyrtone was selected for further study of apoptosis induction in A431 cells. 

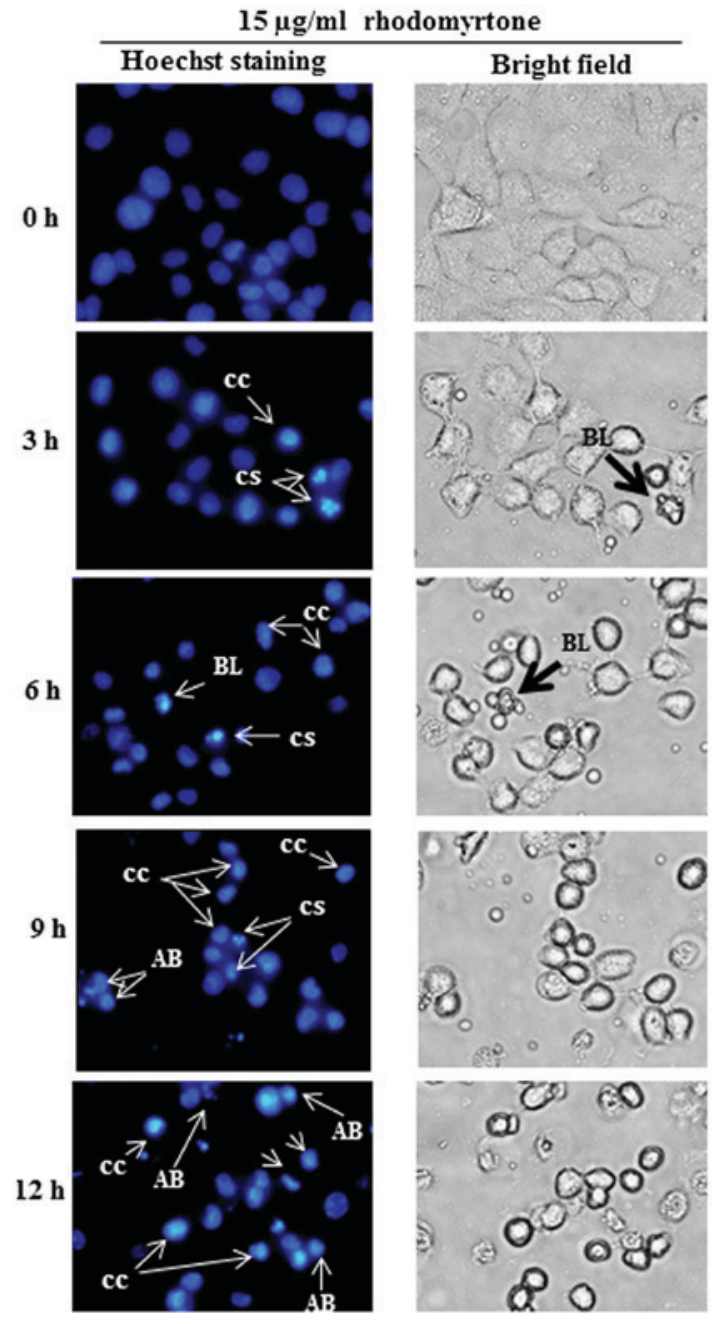

Figure 5. Effect of rhodomyrtone on cell morphological changes. A431 cells were treated with $15 \mu \mathrm{g} / \mathrm{ml}$ of rhodomyrtone for $0,3,6,9,12 \mathrm{~h}$. Cells were stained with Hoechst 33342 and observed under fluorescence microscope (magnification, x40). Arrow points show morphological changes of A431 cells. BL, blebbing; CC, chromatin condensation; AB, apoptotic body; CS, cell shrinkage.

Rhodomyrtone inhibited A431 cell migration. The effect of rhodomyrtone on cell migration was determined by wound healing assay. The cell monolayers were scratched with a micropipette tip to create the wound area. After treatment with non-toxic concentrations $(0.5$ and $1.5 \mu \mathrm{g} / \mathrm{ml})$ of rhodomyrtone for 12 and $24 \mathrm{~h}$, the wound closure was analyzed. The result showed that rhodomyrtone could reduce migration of A431 cells to the wound area in a time- and dose-dependent manner when compared with the untreated cells (Fig. 3A and B). Treatment with rhodomyrtone at 0.5 , $1.5 \mu \mathrm{g} / \mathrm{ml}$ for 12 and $24 \mathrm{~h}$ inhibited 47.3, 36.2, 69.8 and $68.4 \%$ of cell migration, respectively. These results revealed that rhodomyrtone significantly inhibited the migration of A431 cells $(\mathrm{P}<0.01)$.

Rhodomyrtone induced G1 arrest in A431 cells. To identify the mechanism of growth inhibitory effect of rhodomyrtone, the cell cycle distribution of A431 cells were determined by flow cytometry. The results showed that the percentage of cell population in the G1 phase significantly increased after treatment with rhodomyrtone $(15 \mu \mathrm{g} / \mathrm{ml})$ for $12 \mathrm{~h}(\mathrm{P}<0.05)$.
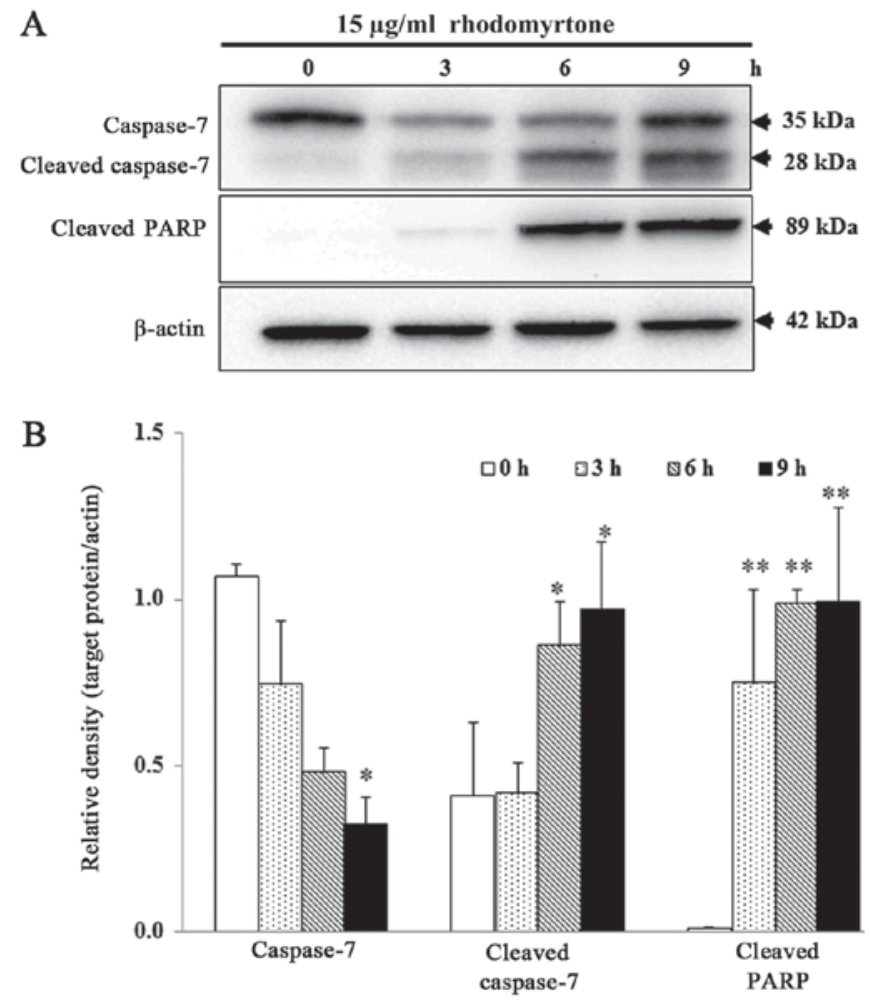

Figure 6. Effect of rhodomyrtone on protein expression levels of caspase-7, cleaved caspase-7 and cleave PARP in A431 cells. Cells were treated with $15 \mu \mathrm{g} / \mathrm{ml}$ of rhodomyrtone for $0,3,6,9 \mathrm{~h}$. The expression of caspase-7, cleaved caspase-7 and cleave PARP were analyzed by western blot analysis (A). The relative density of protein expression was expressed relative to the protein level at $0 \mathrm{~h}$ after normalization to $\beta$-actin signals (B). Data are presented as mean $\pm \mathrm{SD}(\mathrm{n}=3) .{ }^{*} \mathrm{P}<0.05,{ }^{* *} \mathrm{P}<0.01$ compared with the control.

Concomitantly, the percentage of cells in the $S$ phase significantly decreased after treatment for 9 and $12 \mathrm{~h}(\mathrm{P}<0.05)$ (Fig. 4A and B). These results indicated that rhodomyrtone induced G1 phase arrest in A431 cells.

Rhodomyrtone induced cell apoptosis in A431 cells. To observe the morphological changes of treated-cells, Hoechst 33342 staining was performed and observed under fluorescence microscope. After treatment with $15 \mu \mathrm{g} / \mathrm{ml}$ rhodomyrtone for 3 and $6 \mathrm{~h}$, the typical characteristic of apoptosis such as membrane blebbing, chromatin condensation and cell shrinkage were detected. The treated-cells (9 and $12 \mathrm{~h}$ ) showed chromatin condensation and cell shrinkage and apoptotic bodies. The apoptotic body formation was predominant after treatment with $15 \mu \mathrm{g} / \mathrm{ml}$ rhodomyrtone for $12 \mathrm{~h}$, whereas the untreated-cells $(0 \mathrm{~h})$ showed normal nuclear and cellular morphology (Fig. 5). This result indicated that rhodomyrtone could inhibit cell proliferation by inducing cellular apoptosis in A431 cells.

To determine whether rhodomyrtone induce apoptosis in A431 cells, Western blotting was performed to detect the activation of caspase-7 and poly ADP-ribose polymerase (PARP) cleavage, substrate of caspase-7. As shown in Fig. 6A and B, the protein level of cleaved caspase-7 and cleaved PARP significantly increased, while pro-caspase-7 significantly decreased in a time-dependent manner after treatment with $15 \mu \mathrm{g} / \mathrm{ml}$ rhodomyrtone $(\mathrm{P}<0.05)$. 


\section{Discussion}

Rhodomyrtone, an acylphloroglucinol component derived from the leaves of Rhodomyrtus tomentosa, has been used as traditional herb medicine for a long time. The roots, leaves and fruits were used to treat acute and chronic gastroenteritic, stomachache, dysentery, hepatitis, gynaecopathy, dysentery and diarrhoea $(2,3)$. Previous reports have shown that rhodomyrtone exhibited antibacterial activity on gram-positive bacteria (7-10). However, the effects of rhodomyrtone on cancer cells have not yet been reported. In this study, we first demonstrated that rhodomyrtone exhibited an anticancer activity in epidermoid carcinoma A431 cell.

The induction of apoptosis is one of the important mechanisms for an anticancer agent. In this study, we investigated the effects of rhodomyrtone on cell proliferation inhibition, cell cycle arrest and apoptosis induction. The results showed that rhodomyrtone dramatically inhibited A431 cell proliferation in a dose-dependent manner correlated with cell cycle arrest and apoptosis induction. The $\mathrm{IC}_{50}$ of rhodomyrtone against A431 cell lines was found to be $8.04 \pm 0.11 \mu \mathrm{g} / \mathrm{ml}$ after $24 \mathrm{~h}$ treatment as shown in Fig. 2. The morphological characteristics of cells undergo apoptosis including cell shrinkage, chromatin condensation, membrane blebbing and formation of apoptotic bodies (18). Our result demonstrated that rhodomytone induced apoptosis in A431 cells as shown in Fig. 5. Apoptosis can be divided into two major pathways; the extrinsic, caspase-dependent pathway and the mitochondria-dependent pathway (19-21). Caspase-dependent pathways include activation of caspase- $8,-9$ and $-3 / 7$ while mitochondrial pathways are involved in the efflux of cytochrome $c$ from mitochondria to the cytoplasm, forming apoptosomes with Apaf- 1 and caspase-9, leading to the activation of caspase-3/7 and apoptosis (22). In our results, we also demonstrated that rhodomyrtone induced apoptosis in A431 cells via cleavage of caspase-7 and PARP as shown in Fig. 6A and B. Similar to previous reports indicating that bioactive compound induced apoptosis in many types of cancer by activation of caspase and PARP (23-27).

Cell cycle is an important mechanism involved with cell growth. Cell cycle arrest and apoptosis are the effective mechanisms that lead to cancer cell death (28). Previous studies showed that natural bioactive compounds could inhibit human epidermoid carcinoma A431 cells growth by cell cycle arrest and apoptosis induction (24,27,29,30). In the present study, we also investigated the effect of rhodomyrtone on cell cycle of A431 cells. Flow cytometric analysis showed that rhodomyrtone inhibited cell growth of A431 by inducing cell cycle arrest at G1 phase in a time-dependent manner. G1 phase was increased from $36.4 \%$ up to $51.2 \%$ and the cell populations in the $\mathrm{S}$ phase was decreased from 20.4 to $12.0 \%$, implying that cell proliferation inhibition involved with cell cycle arrest (Fig. 4A and B). Similarly, previous study reported that shikonin induced cell cycle arrest in G0/G1 phase and induced apoptosis in A431 cells (24). Although, Soliman et al showed that some acylphloroglucinol compounds exhibited antiproliferative activity and inhibited cell cycle progression at S-phase in breast cancer cell (31). The differences between these results might be attributed to the bioactive compound and cell types tested.
Metastasis is a complication of most cancers; it is one of the leading causes of cancer-related death. Metastasis is a multistep process leading to the formation of secondary tumors from the primary tumor, which the cancer cells disseminate from the primary tumor, migrate through the basement membrane, survive in the circulatory system, invade into a secondary site and start to proliferate (32). Cell migration of cancer cells is an important step in metastasis process. In this study, wound healing assay was performed to determine the anti-migration effect of rhodomyrtone on A431 cells. Our result showed that rhodomyrtone at non-toxic concentrations $(0.5$ and $1.5 \mu \mathrm{g} / \mathrm{ml})$ significantly inhibits A431 cell migration in a dose-dependent manner (Fig. 3A and B).

In conclusion, we first showed that rhodomyrtone induced apoptosis in A431 cells via cleavage of caspase-7 and PARP. Furthermore, rhodomyrtone also caused cell cycle arrest at G1 phase in a time-dependent manner. We also demonstrated that rhodomyrtone dramatically inhibited cell migration in A431 cells at a non-toxic concentration. These finding suggested that rhodomyrtone may be used as an anticancer agent for skin cancer.

\section{Acknowledgements}

We would like to thank the Agricultural Research Development Agency (Public Organization), Thailand, Research Division, Faculty of Medicine, and Research Unit in 'Biological activities of Bioactive Compounds', Srinakharinwirot University.

\section{References}

1. Panthong A, Kanjanapothi D, Taesotiku T and Taylor WC: Ethnobotanical review of medicinal plants from Thai traditional books, Part II: Plants with antidiarrheal, laxative and carminative properties. J Ethnopharmacol 31: 121-156, 1991.

2. Wei F: Manufacture of oral liquid containing traditional Chinese medicine extract for treating gynecopathy [Guangxi Huahong Pharmaceutical Co., Ltd, People's Republic of China; Shanghai Fosun Pharmaceutical (Group) Co., Ltd], Faming Zhuanli Shenqing Gongkai Shuomingshu. China Patent CN1846715. Filed April 13, 2005; issued October 18, 2006.

3. Wei F: Manufacture of traditional Chinese medicine composition for treating urinary tract infection Gungxi Huahong Pharmaceutical Co., Ltd, People's Republic of China; Shanghai Fosun Pharmaceutical (Group) Co., Ltd, Faming Zhuanli Shenqing Gongkai Shuomingshu. China Patent CN1853687, Filed April 29, 2005; issued November 1, 2006.

4. Panthong A, Kanjanapothi D and Taylor WC: Ethnobotanical review of medicinal plants from Thai traditional books, Part I: Plants with anti-inflammatory, anti-asthmatic and antihypertensive properties. J Ethnopharmacol 18: 213-228, 1986.

5. Ong HC and Nordiana M: Malay ethno-medico botany in Machang, Kelantan, Malaysia. Fitoterapia 70: 502-513, 1999.

6. Miyake Y, Nojima J. Skin Cosmetic and Food/Drink for Cosmetrogical Use. Maruzen Pharmaceutical Co., Ltd., Hiroshima, Japan. Japan Patent JP2006199678A. Filed December 6, 2005; issued August 3, 2006.

7. Limsuwan S, Trip EN, Kouwen TR, Piersma S, Hiranrat A, Mahabusarakam W, Voravuthikunchai SP, van Dijl JM and Kayser O: Rhodomyrtone: A new candidate as natural antibacterial drug from Rhodomyrtus tomentosa. Phytomedicine 16: 645-651, 2009.

8. Limsuwan S, Hesseling-Meinders A, Voravuthikunchai SP, van Dijl JM and Kayser O: Potential antibiotic and anti-infective effects of rhodomyrtone from Rhodomyrtus tomentosa (Aiton) Hassk. On Streptococcus pyogenes as revealed by proteomics. Phytomedicine 18: 934-940, 2011.

9. Voravuthikunchai SP, Dolah S and Charernjiratrakul W: Control of Bacillus cereus in foods by Rhodomyrtus tomentosa (Ait.) Hassk. leaf extract and its purified compound. J Food Prot 73: 1907-1912, 2010 
10. Saising J, Ongsakul M and Voravuthikunchai SP: Rhodomyrtus tomentosa (Aiton) Hassk. ethanol extract and rhodomyrtone: A potential strategy for the treatment of biofilm-forming staphylococci. J Med Microbiol 60: 1793-1800, 2011.

11. Srisuwan S, Tongtawe P, Srimanote P and Voravuthikunchai SP: Rhodomyrtone modulates innate immune responses of THP-1 monocytes to assist in clearing methicillin-resistant Staphylococcus aureus. PLoS One 9: e110321, 2014.

12. Chorachoo J, Saeloh D, Srichana T, Amnuaikit T, Musthafa KS, Sretrirutchai S and Voravuthikunchai SP: Rhodomyrtone as a potential anti-proliferative and apoptosis inducing agent in $\mathrm{HaCaT}$ keratinocyte cells. Eur J Pharmacol 772: 144-151, 2016.

13. Scherer D and Kumar R: Genetics of pigmentation in skin cancer-a review. Mutat Res 705: 141-153, 2010.

14. Rigel DS: Cutaneous ultraviolet exposure and its relationship to the development of skin cancer. J Amer Acad Dermatol 58: $129-132,2008$

15. Afaq F: Natural agents: Cellular and molecular mechanisms of photoprotection. Arch Biochem Biophys 50: 144-151, 2011.

16. Bowden GT: Prevention of non-melanoma skin cancer by targeting ultraviolet-B-light signaling. Nat Rev Cancer 4: 23-35, 2004.

17. Lu MK, Shih YW, Chang Chien TT, Fang LH, Huang HC and Chen PS: $\alpha$-Solanine inhibits human melanoma cell migration and invasion by reducing matrix metalloproteinase-2/9 activities. Biol Pharm Bull 33: 1685-1691, 2010.

18. Wyllie AH, Kerr JF and Currie AR: Cell death: The significance of apoptosis. Int Rev Cytol 68: 251-306, 1980.

19. Fan TJ, Han LH, Cong RS and Liang J: Caspase family proteases and apoptosis. Acta Biochim Biophys Sin (Shanghai) 3: 719-727, 2005.

20. Mehmet H: Caspases find a new place to hide. Nature 403: 29-30, 2000

21. Shi Y: Mechanisms of caspase activation and inhibition during apoptosis. Mol Cell 9: 459-470, 2002.

22. Yang J, Liu X, Bhalla K, Kim CN, Ibrado AM, Cai J, Peng TI, Jones DP and Wang X: Prevention of apoptosis by Bcl-2: Release of cytochrome c from mitochondria blocked. Science 275 1129-1132, 1997.

23. Tancharoen W, Teeraaungkul S, Krajarng A, Nilwarangoon S and Watanapokasin R: Apoptosis induction by rafflesia kerrii meijer flower extract via caspase-dependent and down-regulation of ERK signaling pathway in epidermoid carcinoma cells. J Mod Med Chem 1: 37-42, 2013.
24. Tian R, Li Y and Gao M: Shikonin causes cell-cycle arrest and induces apoptosis by regulating the EGFR-NF- $\kappa \mathrm{B}$ signaling pathway in human epidermoid carcinoma A431 cells. Biosci Rep 35: pii: e00189, 2015.

25. Zhu Y, Mao Y, Chen H, Lin Y, Hu Z, Wu J, Xu X, Xu X, Qin J and Xie L: Apigenin promotes apoptosis, inhibits invasion and induces cell cycle arrest of T24 human bladder cancer cells. Cancer Cell Int 13: 54, 2013.

26. Tsang CM, Lau EP, Di K, Cheung PY, Hau PM, Ching YP, Wong YC, Cheung AL, Wan TS, Tong Y, et al: Berberine inhibits Rho GTPases and cell migration at low doses but induces G2 arrest and apoptosis at high doses in human cancer cells. Int J Mol Med 24: 131-138, 2009.

27. Pal CH, Sharma S, Elmets AC, Athar M and Afaq F: Fisetin inhibits growth, induces $\mathrm{G}_{2} / \mathrm{M}$ arrest and apoptosis of human epidermoid carcinoma A431 cells: Role of mitochondrial membrane potential disruption and consequent caspases activation. Exp Dermatol 22: 470-475, 2013.

28. King KL and Cidlowski JA: Cell cycle regulation and apoptosis. Annu Rev Physiol 60: 601-617, 1998.

29. Li D, Wu LJ, Tashiro S, Onodera S and Ikejima T: Oridonin-induced A431 cell apoptosis partially through blockage of the Ras/Raf/ERK signal pathway. J Pharmacol Sci 103: 56-66, 2007.

30. Yim NH, Kim A, Liang C, Cho WK and Ma JY: Guibitang, a traditional herbal medicine, induces apoptotic death in A431 cells by regulating the activities of mitogen-activated protein kinases. BMC Complement Altern Med 14: 344, 2014.

31. Soliman MF, Fathy MM, Salama MM, Al-Abd MA, Saber RF and El-Halawany AM: Cytotoxic activity of acylphloroglucinols isolated from the leaves of Eucalyptus cinerea F. Muell. ex Benth. cultivated in Egypt. Sci Rep 4: 5410, 2014.

32. Bravo-Cordero JJ, Hodgson L and Condeelis J: Directed cell invasion and migration during metastasis. Curr Opin Cell Biol 24: 277-283, 2012. 